\title{
Effect of Production System and Pruning on Temporal Development of Cercospora depazeoides and on Berry Yield in Black Elderberry Orchards
}

\author{
I. J. Holb, University of Debrecen, Centre for Agricultural Sciences and Engineering, P.O. Box 36, H-4015 Debre- \\ cen, Hungary and Plant Protection Institute, Hungarian Academy of Sciences, P.O. Box 102, H-1525 Budapest, Hun- \\ gary; J. M. Gáll, University of Debrecen, Institute of Mathematics and Informatics, P.O. Box 15, H-4015 Debrecen, \\ Hungary; and B. Fodor, University of Debrecen, Centre for Agricultural Sciences and Engineering, P.O. Box 36, H- \\ 4015 Debrecen, Hungary
}

\begin{abstract}
Holb, I. J., Gáll, J. M., and Fodor, B. 2009. Effect of production system and pruning on temporal development of Cercospora depazeoides and on berry yield in black elderberry orchards. Plant Dis. 93:625-631.

In a 2-year study, the temporal development of Cercospora leaf spot (Cercospora depazeoides) and berry yield were evaluated in two production systems (integrated and organic) and in two winter pruning treatments (trees pruned to four and eight scaffolds) in two black elderberry (Sambucus nigra) orchards in Hungary. Under organic production, leaf spot onset occurred 2 to 4 weeks earlier (mid- and late July) in both years and both orchards compared with the integrated program. Disease then continuously progressed until the final assessment date (late September) in both years, reaching a maximum final disease incidence of $15.9 \%$ in the integrated system and of $38.2 \%$ in the organic system. In general, disease progress after late August was greater on trees pruned to eight scaffolds than on trees pruned to four scaffolds in both production systems. Both final disease incidence and area under the disease progress curves (AUDPC) were significantly lower $(P<0.001)$ in the integrated treatments compared with organic ones. Across all treatments, both disease measures were significantly $(P<0.05)$ lower on trees pruned to four scaffolds compared with trees pruned to eight scaffolds. However, when the effect of pruning on final disease incidence and AUDPC was analyzed separately for integrated and organic systems, pruning caused uniformly significant differences in disease development only for the organic system. Berry yield was significantly higher $(P<0.05)$ in the integrated system compared with the organic system, but pruning showed no significant effect on yield. Overall, pruning to four scaffolds resulted in consistently lower disease development in organic production compared to integrated. Thus, winter pruning may be useful as a Cercospora leaf spot management practice in organic elderberry orchards.
\end{abstract}

There is an increasing interest in commercial growing of black elderberry (Sambucus nigra L.) due to increased industrial and medicinal use of elderberry products. Fruits are used in the food industry for processing jelly, jam, and juice as well as concentrated juice which is suitable as a natural colorant of other foods such as confectionery and wine $(22,24,25,35)$. Both fruits and flowers of elderberry are also used for medicinal purposes, as they reduce the risk of virus-induced human diseases (influenza and herpes), cancer, and cardiovascular diseases $(26,38,39$, 46,48). Currently, $S$. nigra is cultivated in a few thousand hectares in several European countries $(22,27)$. Elderberry is presently the leading berry crop in Hungary, as approximately 2,000 ha of commercial elderberry are grown primarily

Corresponding author: I. J. Holb

E-mail: holb@agr.unideb.hu

Accepted for publication 8 February 2009

doi:10.1094/PDIS-93-6-0625

(C) 2009 The American Phytopathological Society using the Austrian-bred cultivar Haschberg $(9,41)$.

Fruit, flower, leaf, and wood of S. nigra can be attacked by more than 200 pests and diseases $(2,10)$. However, only a few pests and diseases cause economic losses in commercial elderberry orchards $(21,24$, $30,33,41,42,47)$, and of these the foliar disease Cercospora leaf spot caused by Cercospora depazeoides (Desm.) Sacc. $(24,30,33,41,42)$ and Botrytis fruit rot caused by Botrytis cinerea Pers.:Fr. $(30,41,47)$ are considered important in most European countries and Japan. Only a few studies are available on disease and pest management programs of elderberry $(24,41,47)$. In a typical spray schedule, four to five sprays are applied against diseases and pests of elderberry annually, depending on weather conditions $(24,41,47)$. In spring, one spray at dormant bud stage and one or two additional sprays during blossom and early fruit set are common. In summer, one spray is applied in July against Cercospora leaf spot and one additional spray is applied in August before harvest against Cercospora leaf spot and Botrytis fruit rot (41). In most European countries and in Japan, Cercospora leaf spot causes damaging disease of elderberry foliage $(30,33,42)$. The disease mainly occurs at late summer and in autumn (41) and can reach a level of $50 \%$ disease incidence at harvest in rainy years if no fungicide control is applied (30). Early defoliation caused by Cercospora leaf spot results in a lower photosynthetic capacity of the tree, which negatively affects the size and industrial quality of the berries $(34,41)$.

Because elderberries require relatively few sprays against pests and diseases, there is an excellent potential for growing elderberry in environmentally benign production systems, including integrated and organic production. According to international organic growing guidelines, only a few fungicides are approved for use against fruit diseases (1), and these are often less effective than modern synthetic fungicides used in integrated fruit growing (6). Previous studies on different fruit crops (e.g., apple, sour cherry) showed that damage caused by diseases is generally more severe in organic orchards compared with integrated ones $(7,16-20)$. However, no studies report an effect of these production systems on temporal development of elderberry diseases, such as Cercospora leaf spot, or on elderberry yields.

An essential orchard management practice is winter pruning, which plays an important role in improving elderberry yield (47). Standard winter pruning practices recommend keeping four to 10 fruitbearing scaffolds that are 1 to $1.5 \mathrm{~m}$ long, depending on age of the trees, planting distance, irrigation, and nutrition supply $(23,34)$. Elderberry yield can range from 8 to $25 \mathrm{tha}^{-1}$ depending on intensity of winter pruning $(23,41)$. Pruning intensity determines the number of leaves and therefore canopy density and size during the season. This may influence microclimate and/or spray deposition within the tree canopy as shown for other fruit crops $(5,8,12,14,29,31,36)$ and as a consequence affect disease incidence. However, no study has examined the effect of pruning on elderberry diseases such as Cercospora leaf spot. If pruning could reduce the incidence of Cercospora leaf spot, it might, in turn, suppress the leaf spot development in elderberry orchards.

The aim of this 2-year study was first to determine whether production systems 
(integrated and organic) have an effect on the temporal progress of Cercospora leaf spot under a continental climate, and second to determine how disease development in commercial elderberry orchards is affected by the degree of winter pruning and location. Effects of production systems and pruning on berry yield were also determined.

\section{MATERIALS AND METHODS}

Orchard location and general orchard management. A 2-year study (2006 and 2007) was carried out in two commercial elderberry orchards in Hungary. One of the orchards was located at $47^{\circ} 53^{\prime} 20^{\prime \prime} \mathrm{N}$ and $20^{\circ} 16^{\prime} 80^{\prime \prime} \mathrm{E}$, in Egerszólát, northeastern Hungary. The other was in Aldebrö, 24 km south of the orchard at Egerszólát. In Egerszólát, the 17-ha orchard was planted in 2000, and between-row and within-row distances were $6 \mathrm{~m}$ and $4 \mathrm{~m}$, respectively. In Aldebrö, the 2.5-ha orchard was planted in 1999, and between-row and within-row distances were $5 \mathrm{~m}$ and $4 \mathrm{~m}$, respectively.

Both orchards were planted with $\mathrm{cv}$. Haschberg and divided into two blocks corresponding to integrated and organic production systems. The two blocks were separated by a 10 - and a $20-\mathrm{m}$-wide road in Egerszólát and Aldebrö, respectively. Orchard soil type was brown forest soil with alternating layers of clay in both orchards. Grass in 0.8-m-wide strips was grown in the rows, and bare soil was maintained in the row centers by using a disktiller on a monthly basis from mid-May through mid-August. Due to better nutrient availability in the integrated orchards, grass in the rows was cut four times each year with an orchard flail mower (midMay, mid-June, mid-July, and mid-August) in the integrated blocks while only three times a year (late May, mid-July, and midAugust) in the organic blocks. None of the orchards were irrigated.

Environmental monitoring. Rainfall $(\mathrm{mm})$ and temperature $\left({ }^{\circ} \mathrm{C}\right)$ were detected at 12-min intervals using Metos Compact agrometeorological stations (Pessl Instrument $\mathrm{GmbH}$, Weiz, Austria) in both orchards from 1 April until 30 September in 2006 and 2007. The agrometeorological stations were located 57 and $26 \mathrm{~m}$ to the northwest of the experimental plots in the orchards at Egerszólát and Aldebrő, respectively, during each season. Detecting sensors were mounted $1.5 \mathrm{~m}$ above the ground in the center of the canopy of a tree during each season at each location. In the experimental plots, a hygrothermograph (Techno Ltd., Budapest, Hungary) was mounted $1.5 \mathrm{~m}$ above the ground in the center of the canopy of one tree pruned to four and another pruned to eight scaffolds during each season at each location.

Experimental design and treatments. At each location, the experimental design was a split-plot with the 2 years as blocks, the two production systems as main plots, and two pruning treatments as subplots. The pest management program in the integrated main plots followed the Hungarian integrated fruit production (IFP) guidelines derived from the European IFP guidelines (6), while those in the organic main plots were according to the Hungarian organic production guidelines derived from the International Federation of Organic Agriculture Movements (IFOAM) organic production guidelines (1). Both sets of guidelines had been applied since the orchards were planted. General spray schedules against diseases and pests in 2006 and 2007 are given in Table 1. In both orchards, all sprays were applied with a Kertitox 2000 axial blower spray machine (Debreceni Gépgyár B.V., Debrecen, Hungary) with a ceramic hollow cone at 1.1 to 1.2 $\mathrm{MPa}$ with a volume of 500 liters $\mathrm{ha}^{-1}$. In the organic blocks, stable manure and compost were applied every other year, while the integrated blocks relied on annual application of synthetic fertilizers for nutrient supply. Each main plot consisted of a minimum of 500 trees.

Within each main plot, two winter pruning treatments were applied: heavy and light pruning. In the heavily pruned treatment, four fruit-bearing scaffolds with a length of $1.5 \mathrm{~m}$ were left on the trees and all other shoots were removed, while in the

Table 1. General orchard spray schedules against diseases and pests on cultivar Haschberg in elderberry orchards (Egerszólát and Aldebrő, Hungary, 20062007)

\begin{tabular}{|c|c|c|c|c|c|c|c|}
\hline \multicolumn{4}{|c|}{ Integrated } & \multicolumn{4}{|c|}{ Organic } \\
\hline Date & $\begin{array}{l}\text { Phenological } \\
\text { stage }\end{array}$ & $\begin{array}{l}\text { Active ingredients, } \\
\text { trade name }{ }^{\mathrm{a}}\end{array}$ & Dosage & Date & $\begin{array}{l}\text { Phenological } \\
\text { stage }\end{array}$ & $\begin{array}{l}\text { Active ingredients, } \\
\text { trade name }^{\mathrm{a}}\end{array}$ & Dosage \\
\hline \multicolumn{8}{|c|}{ Egerszólát 2006} \\
\hline 04 April & Bud swelling & $\begin{array}{l}\text { Copper hydroxide and plant oil, } \\
\text { Vegesol R }\end{array}$ & $0.3 \%$ & 02 April & Bud swelling & $\begin{array}{l}\text { Elementary sulfur and plant oil, } \\
\text { Oleo-Sulfur SC }\end{array}$ & $0.2 \%$ \\
\hline 03 May & Blooming & Malathion, Fyfanon EW & $0.1 \%$ & 06 May & Blooming & Bacillus thuringiensis, Dipel ES & $0.16 \%$ \\
\hline 18 July & Fruit swelling 1 & Captan, Merpan 80 WDG & $0.15 \%$ & 18 July & Fruit swelling 1 & Elementary sulfur, Kumulus S & $0.4 \%$ \\
\hline 29 Sept & After harvest & Copper hydroxide, Funguran-OH & $0.1 \%$ & 30 Sept & After harvest & Copper hydroxide, Champion $50 \mathrm{WP}$ & $0.25 \%$ \\
\hline \multicolumn{8}{|c|}{ Egerszólát 2007} \\
\hline 02 April & Bud swelling & $\begin{array}{l}\text { Copper hydroxide and plant oil, } \\
\text { Vegesol R }\end{array}$ & $0.3 \%$ & 02 April & Bud swelling & $\begin{array}{l}\text { Elementary sulfur and plant oil, } \\
\text { Oleo-Sulfur SC }\end{array}$ & $0.15 \%$ \\
\hline 6 May & Blooming & Malathion, Fyfanon EW & $0.1 \%$ & 06 May & Blooming & Bacillus thuringiensis, Dipel ES & $0.16 \%$ \\
\hline 03 Aug & Fruit swelling 2 & Captan, Merpan 80 WDG & $0.15 \%$ & 20 July & Fruit swelling 1 & Elementary sulfur, Kumulus S & $0.4 \%$ \\
\hline 29 Sept & After harvest & Copper hydroxide, Cuproxat FW & $0.2 \%$ & $30 \mathrm{Sept}$ & After harvest & Copper hydroxide, Champion $50 \mathrm{WP}$ & $0.25 \%$ \\
\hline \multicolumn{8}{|c|}{ Aldebrö 2006} \\
\hline 05 April & Bud swelling & $\begin{array}{l}\text { Copper hydroxide and plant oil, } \\
\text { Vegesol R }\end{array}$ & $0.3 \%$ & 01 April & Bud swelling & $\begin{array}{l}\text { Elementary sulfur and plant oil, } \\
\text { Oleo Sulfur }\end{array}$ & $0.2 \%$ \\
\hline 03 May & Blooming & Malathion, Fyfanon EW & $0.1 \%$ & 06 May & Blooming & Bacillus thuringiensis, Dipel ES & $0.16 \%$ \\
\hline 10 July & Fruit swelling 1 & Captan, Merpan 80 WDG & $0.15 \%$ & 05 July & Fruit swelling 1 & Elementary sulfur, Kumulus S & $0.4 \%$ \\
\hline 07 Aug & Fruit swelling 2 & Folpet, Folpan 80 WDG & $0.15 \%$ & 15 Aug & Fruit ripening & Elementary sulfur, Kumulus S & $0.4 \%$ \\
\hline 27 Sept & After harvest & Copper hydroxide, Champion $50 \mathrm{WP}$ & $0.2 \%$ & 28 Sept & After harvest & Copper hydroxide, Cuproxat FW & $0.2 \%$ \\
\hline \multicolumn{8}{|c|}{ Aldebrő 2007} \\
\hline 02 April & Bud swelling & $\begin{array}{l}\text { Copper hydroxide and plant oil, } \\
\text { Vegesol R }\end{array}$ & $0.3 \%$ & 02 April & Bud swelling & $\begin{array}{l}\text { Copper hydroxide and plant oil, } \\
\text { Vegesol R }\end{array}$ & $0.3 \%$ \\
\hline 06 May & Blooming & Malathion, Fyfanon EW & $0.1 \%$ & 06 May & Blooming & Bacillus thuringiensis, Dipel ES & $0.16 \%$ \\
\hline 30 July & Fruit swelling 2 & Captan, Merpan 80 WDG & $0.15 \%$ & 16 July & Fruit swelling 1 & Elementary sulfur, Kumulus S & $0.4 \%$ \\
\hline \multirow[t]{2}{*}{29 Sept } & After harvest & Copper hydroxide, Cuproxat FW & $0.2 \%$ & 17 Aug & Fruit ripening & Elementary sulfur, Kumulus S & $0.3 \%$ \\
\hline & & & & 28 Sept & After harvest & Copper hydroxide, Champion $50 \mathrm{WP}$ & $0.25 \%$ \\
\hline
\end{tabular}

${ }^{a}$ Cuproxat FW: 350 g liter $^{-1}$ copper sulfate, NuFarm Ltd., Linz, Austria; Kumulus S: 80\% elemental sulfur, BASF Hungaria Ltd., Budapest, Hungary; Funguran-OH 50 WP: 77\% copper hydroxide, Spiess-Urania Chemicals GmbH, Hamburg, Germany; Merpan 80 WDG: 80\% captan, Makhteshim Agan Hungary Ltd., Budapest, Hungary; Folpan 80 WDG: $80 \%$ folpet, Makhteshim Agan Hungary Ltd., Budapest, Hungary; Fyfanon EW: 440 g liter-1 malathion, Cheminova A/S Harboøre, Denmark; Vegesol R: 24\% copper hydroxide and 25\% plant oil, Budapesti Vegyimüvek GmbH, Budapest, Hungary; Oleo-Sulfur SC: BÉVÉEM Ltd., Budapest, Hungary; Dipel ES: 3.2\% Bacillus thuringiensis, Valent BioSciences, USA; Champion 50 WP: $77 \%$ copper hydroxide, NuFarm Hungaria Ltd., Budapest, Hungary. Fruit developmental stages of elderberry are: fruit setting, fruit swelling 1, fruit swelling 2, fruit ripening. 
lightly pruned treatments eight fruit bearing scaffolds with a length of $1.5 \mathrm{~m}$ were left on the trees. Selected scaffolds were healthy and centered in the middle of the tree. Trees were pruned once annually, before budbreak, on 24 and 26 February in 2006 and on 21 and 25 February in 2007 at Egerszólát and Aldebrö, respectively. Pruning treatments were in four replicates, and each treatment replicate plot consisted of a minimum of 15 trees for each location and production system.

Assessment of Cercospora leaf spot and yield. Within each subplot, 10 trees were selected randomly for Cercospora leaf spot assessments every 2 weeks from 30 April until 30 September. Two fruitbearing scaffolds were selected randomly on each observed tree and at each assessment date. Leaf spot was assessed on all leaves of the selected fruit-bearing woody shoots. Leaves were considered to be diseased if at least one visible leaf spot lesion was present on one leaf. Disease incidence was calculated as the percentage of leaves with at least one leaf spot lesion. For each production system and pruning treatment, the temporal dynamics of leaf spot epidemics were summarized in the area under the disease progress curve (AUDPC) (3). AUDPC (percent-days) was calculated as:

$$
\mathrm{AUDPC}=\sum_{i}^{n-1}\left(\frac{y_{i}+y_{i+1}}{2}\right) \times\left(t_{i+1}-t_{i}\right)
$$

where $n$ is the total number of assessments, $y_{i}$ is the disease incidence at the $i$ th assessment date, and the term $t_{i+1}-t_{i}$ is the time duration between two assessments. Leaf spot severity as well as corresponding AUDPC were also calculated, but the significant differences between treatments for severity were similar to those for incidence; therefore, only incidence values were retained for analysis.

Fruit yield was recorded on 26 and 30 August in 2006 and 2007, respectively, when all fruits per tree were picked and weighed for each production system and pruning treatment.

Data analyses. Data from the two locations were analyzed separately. Final leaf spot incidence and AUDPC as well as yield values were analyzed by split-plot analysis of variance (Statistical Analysis System v. 8.1; SAS Institute, Cary, NC) in order to determine the effect of year, production system, pruning, and their interac- tions. Means were separated by an unprotected least significance difference (LSD) test using $\mathrm{LSD}_{0.05}$ values. Prior to the analyses, disease incidence and severity values were arcsine-square root transformed. Then the four treatments (treatments 1 and 2 are pruning treatments with four and eight fruit-bearing scaffolds, respectively, in the integrated block; and treatments 3 and 4 are pruning treatments with four and eight bearing scaffolds, respectively, in the organic block) were partitioned into preplanned contrasts including: (i) treatments 1 and 2 for both years versus treatments 3 and 4 for both years; (ii) treatments 1 and 3 for both years versus treatments 2 and 4 for both years; (iii) treatment 1 for both years versus treatment 2 for both years; (iv) treatment 3 for both years versus treatment 4 for both years; and (v) treatments 1 to 4 for 2006 versus treatments 1 to 4 for 2007. Contrasts were built into the GenStat ANOVA using the 'Comp' function (Genstat 5 Release 9.1; Lawes Agricultural Trust, IACR, Rothamsted, UK).

\section{RESULTS}

Environmental monitoring. In Egerszólát, monthly mean temperature ranged

Egerszólát

Aldebrö
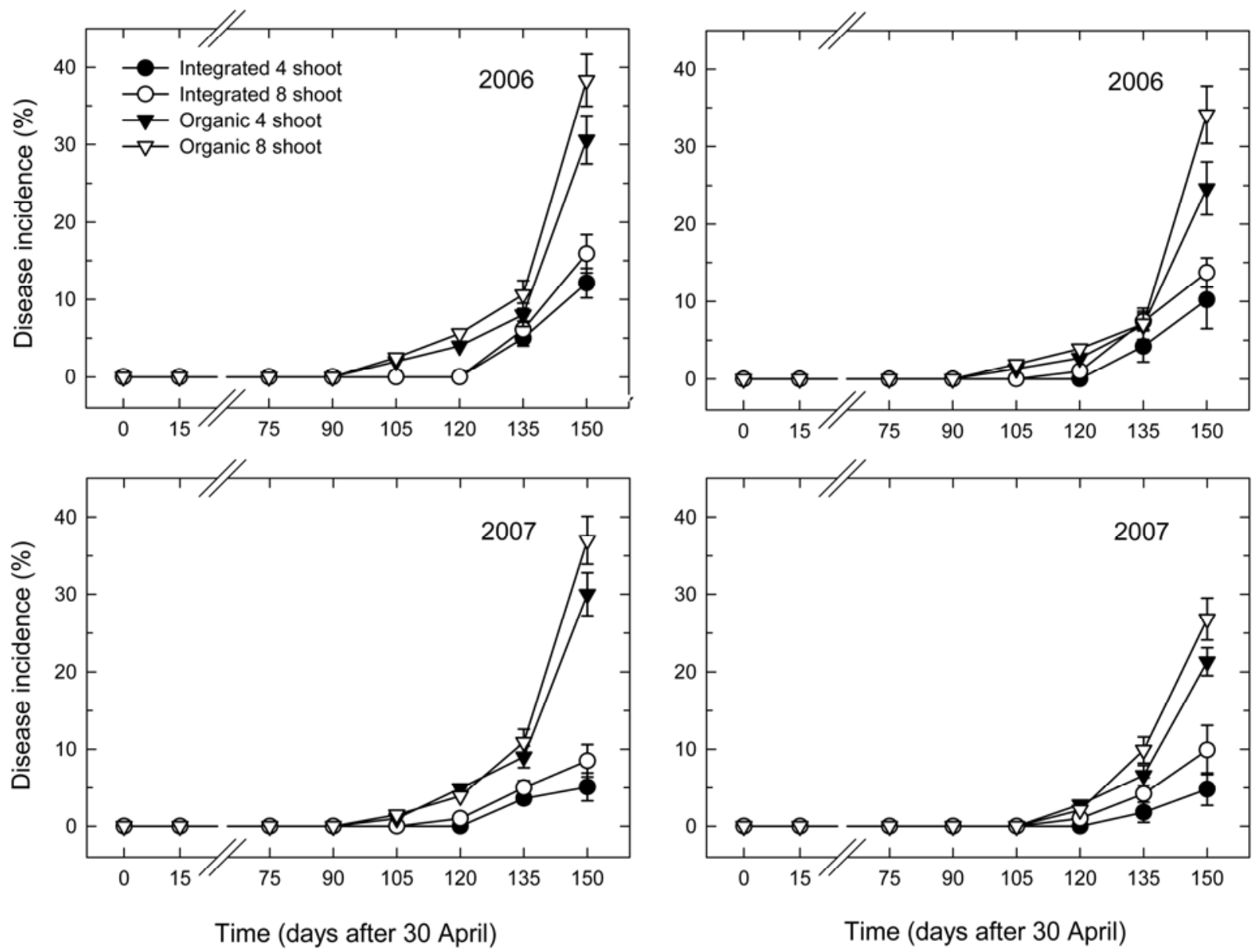

Fig. 1. Progress curves for incidence levels of Cercospora leaf spot (Cercospora depazeoides) in two production systems (integrated and organic) and in two winter pruning treatments (four and eight fruit-bearing scaffolds) on cultivar Haschberg in Hungarian elderberry orchards (Egerszólát and Aldebrö, 20062007). Each data point is the mean of four plots, and error bars represent standard errors. 
from 6.6 to $22.8^{\circ} \mathrm{C}$ and from 3.4 to $24.1^{\circ} \mathrm{C}$ in 2006 and 2007, respectively, from 1 April to 30 September. Rainfall amounts during the growing seasons were 267.8 and $255.3 \mathrm{~mm}$ in 2006 and 2007 in Egerszólát, respectively. In Aldebrö, monthly mean temperature ranged from 6.9 to $22.6^{\circ} \mathrm{C}$ and from 3.6 to $23.5^{\circ} \mathrm{C}$ in 2006 and 2007 , respectively, from 1 April to 30 September. Rainfall amounts during the growing seasons were 240.8 and $212.6 \mathrm{~mm}$ in 2006 and 2007 in Aldebrö, respectively. There were no consistent differences in temperature or relative humidity within canopies of a tree pruned to four and eight scaffolds (data not shown).

Disease progress. In the integrated production system, disease progress curves for leaf spot started in mid-August (on day 105 ) in both years and locations except for Egerszólát in 2006, when the disease progress curves started at late August (on day 120) (Fig. 1). Then disease incidence increased continuously until late September (day 150). Temporal disease progress at the last three assessment dates indicated a larger increase on trees pruned to eight scaffolds compared to trees pruned to four scaffolds (Fig. 1).

In the organic production system, disease symptoms were first observed 2 to 4 weeks earlier (mid- and late July, days 75 and 90) in both years and locations compared to the integrated production system (Fig. 1). Disease incidence then increased continuously until late September (day 150), but an exponential increase of disease development was observed from early September (day 135). Disease incidence after late July (day 90) indicated a larger increase on trees pruned to eight scaffolds compared to trees pruned to four scaffolds (Fig. 1).

Final disease incidence. Analysis of variance of final leaf spot incidence indicated significant differences $(P<0.05)$ between the two production systems, two pruning treatments, and 2 years at both locations (Table 2).

For both years and locations, means of final leaf incidence ranged from 4.9 to $15.9 \%$ and from 21.1 to $38.2 \%$ for the integrated and organic production systems, respectively; and from 4.9 to $30.7 \%$ and from 8.4 to $38.2 \%$ for trees pruned to four and eight scaffolds, respectively (Table 3 ). In both years and locations, the highest leaf spot incidences were observed in those organically treated plots where trees were pruned to eight scaffolds (treatment 4), while the lowest values were assessed in those integrated plots where trees were pruned to four scaffolds (treatment 1).

Table 3. Effect of two production systems (integrated and organic) and two pruning treatments (four and eight fruit-bearing scaffolds) on final leaf spot incidence (\%) caused by Cercospora depazeoides on cultivar Haschberg in elderberry orchards (Egerszólát and Aldebrö, Hungary, 2006-2007)

\begin{tabular}{|c|c|c|c|c|}
\hline \multirow[b]{2}{*}{ Treatments ${ }^{a} /$ location and year } & \multicolumn{2}{|c|}{ Egerszólát } & \multicolumn{2}{|c|}{ Aldebrő } \\
\hline & 2006 & 2007 & 2006 & 2007 \\
\hline IntegratedPruning4 (1) & 12.2 & 5.1 & 10.2 & 4.9 \\
\hline IntegratedPruning8 (2) & 15.9 & 8.4 & 13.6 & 9.6 \\
\hline OrganicPruning4 (3) & 30.7 & 30.2 & 25.7 & 21.1 \\
\hline OrganicPruning8 (4) & 38.2 & 37.2 & 34.2 & 27.3 \\
\hline $\mathrm{LSD}_{0.05}$ & \multicolumn{2}{|c|}{5.52} & \multicolumn{2}{|c|}{5.41} \\
\hline \multicolumn{5}{|l|}{ Significance of contrasts ${ }^{b}$} \\
\hline Int vs. Org & \multicolumn{2}{|c|}{$<0.001^{\mathrm{c}}$} & \multicolumn{2}{|c|}{$<0.001$} \\
\hline Prun 4 vs. Prun8 & \multicolumn{2}{|c|}{0.016} & \multicolumn{2}{|c|}{0.007} \\
\hline IntPrun4 vs. IntPrun8 & \multicolumn{2}{|c|}{0.112} & \multicolumn{2}{|c|}{0.089} \\
\hline OrgPrun 4 vs. OrgPrun8 & \multicolumn{2}{|c|}{0.033} & \multicolumn{2}{|c|}{0.019} \\
\hline 2006 vs. 2007 & \multicolumn{2}{|c|}{0.040} & \multicolumn{2}{|c|}{0.008} \\
\hline
\end{tabular}

${ }^{\mathrm{a}}$ IntegratedPruning $4=$ heavily pruned treatment (four fruit-bearing scaffolds on a tree) in integrated orchard; IntegratedPruning 8 = lightly pruned treatment (eight fruit-bearing scaffolds on a tree) in integrated orchard; OrganicPruning $4=$ heavily pruned treatment (four fruit-bearing scaffolds on a tree) in organic orchard; and OrganicPruning8 = lightly pruned treatment (eight fruit-bearing scaffolds on a tree) in organic orchard.

b (i) Int vs. Org $=$ treatments 1 and 2 for both years vs. treatments 3 and 4 for both years; (ii) Prun 4 vs. Prun $8=$ treatments 1 and 3 for both years vs. treatments 2 and 4 for both years; (iii) IntPrun 4 vs. IntPrun $8=$ treatment 1 for both years vs. treatment 2 for both years; (iv) OrgPrun 4 vs. OrgPrun $8=$ treatment 3 for both years vs. treatment 4 for both years; and (v) 2006 vs. $2007=$ treatments 1 to 4 for 2006 vs. treatments 1 to 4 for 2007

${ }^{\mathrm{c}}$ Probability values from analyses of variance. Values in bold represent significance level at $P<0.05$.

Table 2. Analysis of variance for the effects of year (2006 and 2007), production system (integrated and organic), and pruning (four and eight fruit-bearing scaffolds) on final leaf spot incidence (\%) caused by Cercospora depazeoides, area under the disease progress curve (AUDPC) of leaf spot incidence, and yield in elderberry orchards (Egerszólát and Aldebrö, Hungary)

\begin{tabular}{|c|c|c|c|c|c|c|c|c|c|c|}
\hline \multirow[b]{2}{*}{ Source of variation } & \multirow[b]{2}{*}{$\mathbf{d f}^{\mathbf{b}}$} & \multicolumn{3}{|c|}{ Final leaf spot incidence ${ }^{a}$} & \multicolumn{3}{|c|}{ AUDPC } & \multicolumn{3}{|c|}{ Yield } \\
\hline & & $\mathbf{M S}^{\mathbf{c}}$ & $F^{d}$ & $P^{e}$ & MS & $F$ & $P$ & MS & $F$ & $P$ \\
\hline \multicolumn{11}{|l|}{ Egerszólát } \\
\hline Year $(Y)$ & 1 & 67.45 & 24.40 & 0.0481 & $34,777.78$ & 33.54 & 0.0478 & 22.84 & 48.45 & 0.0497 \\
\hline Production system (S) & 1 & $1,111.56$ & 402.60 & 0.0494 & $229,774.21$ & 210.72 & 0.0438 & 127.11 & 254.88 & 0.0397 \\
\hline Main plot error & 1 & 2.76 & & & $1,090.44$ & & & 0.51 & & \\
\hline Pruning $(\mathrm{P})$ & 1 & 59.95 & 737.86 & 0.0014 & $11,981.52$ & 29.77 & 0.0320 & 17.23 & 7.72 & 0.1116 \\
\hline $\mathrm{S} \times \mathrm{P}$ & 1 & 0.14 & 1.71 & 0.4165 & $1,118.64$ & 2.78 & 0.2374 & 0.54 & 0.23 & 0.6838 \\
\hline Subplot error & 1 & 0.08 & & & 402.51 & & & 2.24 & & \\
\hline \multicolumn{11}{|l|}{ Aldebrő } \\
\hline Year $(Y)$ & 1 & 58.86 & 209.28 & 0.0439 & $19,480.64$ & 79.46 & 0.0452 & 12.33 & 2.34 & 0.0448 \\
\hline Production system (S) & 1 & 614.25 & $2,184.20$ & 0.0136 & $101,835.84$ & 417.01 & 0.0312 & 125.24 & 20.56 & 0.0473 \\
\hline Main plot error & 1 & 0.28 & & & 244.21 & & & 6.09 & & \\
\hline Pruning (P) & 1 & 69.03 & 36.21 & 0.0265 & $16,817.78$ & 284.08 & 0.0035 & 7.79 & 1.23 & 0.0481 \\
\hline $\mathrm{S} \times \mathrm{P}$ & 1 & 2.53 & 1.33 & 0.368 & 2.01 & 0.03 & 0.8711 & 12.24 & 1.87 & 0.2998 \\
\hline Subplot error & 1 & 1.91 & & & 59.20 & & & 6.52 & & \\
\hline
\end{tabular}

a Based on arcsine-square root transformed disease incidence data.

$\mathrm{b}$ df $=$ degree of freedom.

c MS = mean square.

${ }^{\mathrm{d}} F=F$ test.

e $P=$ probability values from analyses of variance. 
significantly lower $(P<0.05)$ in 2007 compared to 2006 (Table 3 ).

AUDPC for disease incidence. Similarly to analyses of final leaf spot incidence, analysis of variance of AUDPC for leaf spot incidence indicated significant differences $(P<0.05)$ between the two production systems, two pruning treatments, and 2 years at both locations (Table 2).

In both years and locations, the highest AUDPC for leaf spot incidences were observed in those organically treated plots where trees were pruned to eight scaffolds (treatment 4), while the lowest values were assessed in those integrated plots where trees were pruned to four scaffolds (treatment 1) (Table 4). Again, AUDPC for leaf spot incidence was significantly lower $(P<$ $0.05)$ in the integrated treatments compared to the organically managed plots as well as on trees pruned to four scaffolds compared to those trees pruned to eight scaffolds. When the effect of pruning on leaf spot incidence was analyzed separately for the two productions systems, pruning caused uniformly significant differences in AUDPC values only for the organic production system. Effect of pruning on AUDPC values was significant only at the Aldebrö location for the integrated plots (Table 4). AUDPC similarly to final leaf spot incidence was significantly lower $(P<0.05)$ in 2007 compared to 2006 (Table 4).

Berry yield. Analysis of variance of berry yield indicated significant differences $(P<0.05)$ between the two production systems and the 2 years at both locations (Table 2). Pruning caused significant differences in yield only at the Aldebrö location in both years.

For both years and locations, means of berry yield ranged from 25.7 to $34.7 \mathrm{~kg}$ tree $^{-1}$ and from 18.1 to $26.1 \mathrm{~kg}$ tree ${ }^{-1}$ for the integrated and organic production systems, respectively; and from 19.7 to 34.7 $\mathrm{kg}$ tree ${ }^{-1}$ and from 18.1 to $33.2 \mathrm{~kg}_{\text {tree }}{ }^{-1}$ for trees pruned to four and eight scaffolds, respectively (Table 5). The highest yield $\left(34.7 \mathrm{~kg} \mathrm{tree}{ }^{-1}\right)$ was harvested in the integrated orchard at Egerszólát, while the lowest yield $\left(18.1 \mathrm{~kg}\right.$ tree $\left.^{-1}\right)$ was measured in the organic block at the Aldebrö location.

Yield was significantly higher $(P<$ 0.05 ) in the integrated plots (treatments 1 and 2) compared to organic plots (treatments 3 and 4) (Table 5). Pruning had no significant effect on yield (Table 5). Again, yield was significantly lower $(P<0.05)$ in 2007 compared to 2006 (Table 5).

\section{DISCUSSION}

Our study was the first to describe the temporal development of Cercospora leaf spot in integrated and organic elderberry production systems. The highest incidence of Cercospora leaf spot was below $10 \%$ at harvest (late August) in both production systems. The relatively low incidence of leaf spot at harvest can be explained by the one or two fungicide sprays applied in July or August in both production systems. Even so, an exponential increase of leaf spot incidence (reaching 38.2\%) was observed in both orchards during the month after harvest (in late September) when no fungicide treatments were applied (Fig. 1 and Table 1).

Results of this study demonstrated that the amount of leaf spot inoculum was greater and the temporal progress of the disease was faster in the organic blocks compared to the integrated ones. This may be due to the differences in the efficacy of fungicides in the two production systems. Copper and sulfur fungicides used in organic fruit production provide less effective disease control compared to synthetic fungicides approved in integrated fruit production $(7,16-18,32,45)$, but specific studies on disease management against $C$. depazeoides are not available. Copper can sufficiently control Cercospora spp. in a preventive spray schedule; however, copper sprays against Cercospora spp. could not provide a level of control equivalent to

Table 4. Effect of two production systems (integrated and organic) and two pruning treatments (four and eight fruit-bearing scaffolds) on the area under the disease progress curve (AUDPC) of leaf spot incidence caused by Cercospora depazeoides on cultivar Haschberg in elderberry orchards (Egerszólát and Aldebrö, Hungary, 2006-2007)

\begin{tabular}{|c|c|c|c|c|}
\hline \multirow[b]{2}{*}{ Treatments $\%$ location and year } & \multicolumn{2}{|c|}{ Egerszólát } & \multicolumn{2}{|c|}{ Aldebrö } \\
\hline & 2006 & 2007 & 2006 & 2007 \\
\hline IntegratedPruning4 (1) & 164.5 & 92.6 & 139.6 & 56.5 \\
\hline IntegratedPruning8 (2) & 211.3 & 153.5 & 228.7 & 152.1 \\
\hline OrganicPruning4 (3) & 439.6 & 448.7 & 348.4 & 300.9 \\
\hline OrganicPruning8 (4) & 567.4 & 522.3 & 449.1 & 381.3 \\
\hline $\mathrm{LSD}_{0.05}$ & \multicolumn{2}{|c|}{30.71} & \multicolumn{2}{|c|}{30.21} \\
\hline \multicolumn{5}{|l|}{ Significance of contrasts ${ }^{b}$} \\
\hline Int vs. Org & \multicolumn{2}{|c|}{$<0.001^{\mathrm{c}}$} & \multicolumn{2}{|c|}{$<0.001$} \\
\hline Prun 4 vs. Prun8 & \multicolumn{2}{|c|}{0.001} & \multicolumn{2}{|c|}{$<0.001$} \\
\hline IntPrun4 vs. IntPrun8 & \multicolumn{2}{|c|}{0.063} & \multicolumn{2}{|c|}{0.011} \\
\hline OrgPrun4 vs. OrgPrun8 & \multicolumn{2}{|c|}{0.003} & \multicolumn{2}{|c|}{0.001} \\
\hline 2006 vs. 2007 & \multicolumn{2}{|c|}{0.031} & \multicolumn{2}{|c|}{0.004} \\
\hline
\end{tabular}

a IntegratedPruning4 = heavily pruned treatment (four fruit-bearing scaffolds on a tree) in integrated orchard; IntegratedPruning8 = lightly pruned treatment (eight fruit-bearing scaffolds on a tree) in integrated orchard; OrganicPruning4 = heavily pruned treatment (four fruit-bearing scaffolds on a tree) in organic orchard; and OrganicPruning 8 = lightly pruned treatment (eight fruit-bearing scaffolds on a tree) in organic orchard.

b (i) Int vs. Org = treatments 1 and 2 for both years vs. treatments 3 and 4 for both years; (ii) Prun 4 vs. Prun $8=$ treatments 1 and 3 for both years vs. treatments 2 and 4 for both years; (iii) IntPrun4 vs. IntPrun8 = treatment 1 for both years vs. treatment 2 for both years; (iv) OrgPrun4 vs. OrgPrun8 = treatment 3 for both years vs. treatment 4 for both years; and (v) 2006 vs. $2007=$ treatments 1 to 4 for 2006 vs. treatments 1 to 4 for 2007.

c Probability values from analyses of variance. Values in bold represent significance level at $P<0.05$.

Table 5. Effect of two production systems (integrated and organic) and two pruning treatments (four and eight fruit-bearing scaffolds) on yield $\left(\mathrm{kg}^{-1}\right.$ tree $\left.{ }^{-1}\right)$ of cultivar Haschberg in elderberry orchards (Egerszólát and Aldebrö, Hungary, 2006-2007)

\begin{tabular}{|c|c|c|c|c|}
\hline \multirow[b]{2}{*}{ Treatments ${ }^{a} /$ location and year } & \multicolumn{2}{|c|}{ Egerszólát } & \multicolumn{2}{|c|}{ Aldebrö } \\
\hline & 2006 & 2007 & 2006 & 2007 \\
\hline IntegratedPruning4 (1) & 29.7 & 34.7 & 26.2 & 32.1 \\
\hline IntegratedPruning8 (2) & 31.3 & 33.2 & 25.7 & 29.8 \\
\hline OrganicPruning4 (3) & 21.8 & 26.1 & 19.7 & 23.5 \\
\hline OrganicPruning8 (4) & 24.2 & 24.8 & 21.3 & 18.1 \\
\hline $\mathrm{LSD}_{0.05}$ & \multicolumn{2}{|c|}{4.43} & \multicolumn{2}{|c|}{4.58} \\
\hline \multicolumn{5}{|l|}{ Significance of contrasts ${ }^{b}$} \\
\hline Int vs. Org & \multicolumn{2}{|c|}{$0.001^{\mathrm{c}}$} & \multicolumn{2}{|c|}{0.006} \\
\hline Prun 4 vs. Prun 8 & \multicolumn{2}{|c|}{0.311} & \multicolumn{2}{|c|}{0.123} \\
\hline IntPrun 4 vs. IntPrun8 & \multicolumn{2}{|c|}{0.605} & \multicolumn{2}{|c|}{0.236} \\
\hline OrgPrun4 vs. OrgPrun8 & \multicolumn{2}{|c|}{0.488} & \multicolumn{2}{|c|}{0.181} \\
\hline 2006 vs. 2007 & \multicolumn{2}{|c|}{0.046} & \multicolumn{2}{|c|}{0.035} \\
\hline
\end{tabular}

a IntegratedPruning4 = heavily pruned treatment (four fruit-bearing scaffolds on a tree) in integrated orchard; IntegratedPruning8 = lightly pruned treatment (eight fruit-bearing scaffolds on a tree) in integrated orchard; OrganicPruning 4 = heavily pruned treatment (four fruit-bearing scaffolds on a tree) in organic orchard; and OrganicPruning 8 = lightly pruned treatment (eight fruit-bearing scaffolds on a tree) in organic orchard.

b (i) Int vs. Org = treatments 1 and 2 for both years vs. treatments 3 and 4 for both years; (ii) Prun 4 vs. Prun $8=$ treatments 1 and 3 for both years vs. treatments 2 and 4 for both years; (iii) IntPrun 4 vs. IntPrun $8=$ treatment 1 for both years vs. treatment 2 for both years; (iv) OrgPrun 4 vs. OrgPrun $8=$ treatment 3 for both years vs. treatment 4 for both years; and (v) 2006 vs. $2007=$ treatments 1 to 4 for 2006 vs. treatments 1 to 4 for 2007.

c Probability values from analyses of variance. Values in bold represent significance level at $P<0.05$. 
the synthetic fungicides (13). For instance, copper hydroxide and copper sulfate against $C$. brassicicola were shown not to be useful alternatives to benomyl due to a combination of phytotoxicity and ineffective disease control (28). Due to the phytotoxicity of copper fungicides, copper compounds are limited to dormant sprays or not used at all until after fruit harvest in many fruit crops in organic fruit production $(15,43)$. Copper is replaced with sulfur fungicides during fruit swelling and fruit ripening stages in organic elderberry production (B. Fodor, unpublished). Because of the poor performance of sulfur fungicides in the preharvest season, a copper spray in autumn (late September) was applied in this study in order to reduce overwintering inoculum of leaf spot on fallen leaves. This spray might stop further infection on leaves, as leaf spot incidences on fallen leaves in November remained below $15 \%$ in the integrated and below $40 \%$ in the organic orchards. These values were similar to those observed in late September (I. J. Holb, unpublished).

Pruning of trees enables management of tree shapes, increased growth of fruiting spurs, improved fruit coloration, and management of disease by the removal of diseased stems or dead wood that can harbor pathogens. Pruning may also increase air movement within the tree canopy, which facilitates quicker drying of plant surfaces and a more uniform application of pesticides $(4,29,40)$. Our data indicated that pruning significantly influenced the incidence of Cercospora leaf spot in elderberry orchards (Table 2). However, the effect of pruning on severity of leaf spot incidence was dependent on the orchard production system. In the organic orchards, both measures of leaf spot were significantly lower on trees pruned to four scaffolds in both years and at both locations compared with trees pruned to eight scaffolds (Tables 3 and 4). However, in the integrated orchards, the effect of pruning on the development of leaf spot could be demonstrated only at the Aldebrö location and only on AUDPC values (Table 4). The nonsignificant effect of pruning on leaf spot in the integrated orchards may have been due to the efficacy of fungicides and the resulting low levels of inoculum in those plots. However, in organic fruit production, as fungicides alone are not as effective as in the integrated system, other management practices might play an important role in disease management $(7,16-18)$. In organic elderberry orchards, the risk of leaf spot epidemics can be high because of the large amount of leaf spot inoculum overwintering on leaves generating high levels of initial inoculum during the next growing season. Our study showed that winter pruning in organic elderberry orchards could reduce the amount of leaf spot by late September and resulted in lower AUDPC values on trees pruned to four scaffolds than on trees pruned to eight scaffolds (Tables 3 and 4).

In some previous studies, the effect of pruning on plant diseases has been related to the different microclimates of pruned and unpruned plants. Gubler et al. (12) and English et al. (8) demonstrated that Botrytis bunch rot of grape can be suppressed by the removal of leaves from around flower clusters. This reduction in disease was related to different microclimate parameters, with wind speed being the most important. However, for the most part, differences in disease incidence and severity have been difficult to explain based on the measured differences in environmental factors such as temperature, relative humidity, or wetness duration. In apple orchards, Ocamb-Basu et al. (31) reported that sooty blotch severity of fruits at harvest averaged $9 \%$ less in the winter-pruned trees than in the unpruned ones, while Cooley et al. (5) showed that summer pruning reduced flyspeck incidence by an average of $50 \%$ in unsprayed trees. In addition, Holb (14) demonstrated that intense winter pruning significantly decreased leaf and fruit scab on susceptible apple cultivars compared to unpruned ones. The summer pruning study related decreased disease with a small but significant decrease in relative humidity. However, the other studies agree with this study and indicated that there were no consistent differences in temperature and relative humidity between lightly and heavily pruned trees. It needs to be emphasized that relative humidity and temperature variables are relatively conserved spatially in field crops, while the duration of leaf wetness (LWD), as the key moisture variable, is far more variable spatially $(11,37)$. In-canopy comparisons of LWD were not made for the pruning treatments in this study. However, in agreement with Ocamb-Basu et al. (31), Cooley (5), and Holb (14), we suggest that pruning alters the microclimate of leaves by increasing air movement and light penetration, decreasing the length of wetting periods and high RH periods, thereby slowing leaf spot development on leaves of elderberry trees.

In addition, the reduction observed in the disease in part may also be a result of a more efficient fungicide deposition in pruned trees. Research in North Carolina, Massachusetts, and Hungary found that spray deposition was heavier and less variable on leaves in well-pruned apple trees than in unpruned ones $(5,14,40,44)$. This is probably a result of a more uniform penetration and distribution of spraying material. Although fungicide deposition on elderberry trees was not measured, it is reasonable to expect a similar effect of tree pruning on spray deposition for elderberry trees, as the trees in this experiment were relatively large with dense canopies. Thus, an improved spray penetration, resulting from pruning, is likely to be a supplement to a possible micro-environmental difference in LWD, which may result in the reduction of leaf spot in elderberry leaves in well-pruned organic orchards.

This study demonstrated that elderberry yield was consistently affected by production systems but pruning had no significant effect on yield (Table 5). The larger yield in integrated orchards can be explained by differences in orchard management practices (such as type of fertilizers allowed, and efficacy and phytotoxicity of fungicides approved) in integrated orchards compared with organic ones. The nonsignificant effect of pruning on yield can be related to the physiology of berry development. Trees pruned to four scaffolds produce lower numbers of berries than trees pruned to eight scaffolds; however, the weight of a single berry is higher on trees pruned to four than to eight scaffolds. These phenomena may cancel each other by harvest so that the yield is equivalent in the trees pruned to either four or eight scaffolds. Although berry size is not an essential issue in the marketing position of elderberry, exceptionally small fruit have a low industrial value which can result in a lower market price. Pruning may have a larger effect on yield in growing regions where the annual precipitation is greater than in Hungary. In these regions, leaf spot infections may occur earlier on lightly pruned trees than in Hungary. This could potentially result in more severe symptoms and partial defoliation influencing the overall photosynthetic activity in infected trees. This would reduce berry development and total yield on lightly pruned elderberry trees compared with heavily pruned ones.

In summary, this is the first study to demonstrate that production system had a consistent effect on the temporal development of Cercospora leaf spot and on berry yield of elderberry trees. The effect of pruning on Cercospora leaf spot may both improve spray penetration in the tree and modify the canopy microclimate; however, more research is needed to determine the key mechanism behind disease reduction in elderberry orchards brought about by winter tree pruning. Pruning of elderberry trees as a management tactic for control of Cercospora leaf spot may be a useful management practice in organic elderberry growing.

\section{ACKNOWLEDGMENTS}

We thank Andrew Fieldsend (University of Debrecen, Centre for Agricultural Sciences and Engineering) for his critical reading of the manuscript. Thanks are also due to József Holb for his excellent cooperation. This research was supported partly by grants of the Hungarian Scientific Research Fund and the NKTH-OM-00227/2008 as well as by a János Bolyai Research Fellowship awarded to Imre Holb.

\section{LITERATURE CITED}

1. Anonymous. 2000. IFOAM Basic Standards for Organic Production and Processing. 
Tholey-Theley Press, New York.

2. Atkinson, M. D., and Atkinson, E. 2002. Biological flora of the British Isles: Sambucus nigra L. J. Ecol. 90:895-923.

3. Campbell, C. L., and Madden, L. V. 1990. Introduction to Plant Disease Epidemiology. John Wiley \& Sons, New York.

4. Childers, N., Morris, J. R., and Sibbett, G. S. 1995. Modern Fruit Science: Orchard and Small Fruit Culture. Horticultural Publications, Gainesville, FL.

5. Cooley, D. R., Gamble, J. W., and Autio, W. R. 1997. Summer pruning as a method for reducing flyspeck disease on apple fruit. Plant Dis. 81:1123-1126.

6. Cross, J. V., and Dickler, E. 1994. Guidelines for integrated production of pome fruits in Europe. Technical guideline III. IOBC/WPRS Bull. 17(9): 1-8

7. Ellis, M. A., Ferree, D. C., Funt, R. C., and Madden, L. V. 1998. Effects of an apple scabresistant cultivar on use patterns of inorganic and organic fungicides and economics of disease control. Plant Dis. 82:428-433.

8. English, J. T., Thomas, C. S., Marois, J. J., and Gubler, W. D. 1989. Microclimates of grapevine canopies associated with leaf removal and control of Botrytis bunch rot. Phytopathology 79:395-401.

9. Ferencz, A. 2005. Issues of work organisation and economic evaluation in elderberry production. Horticulture 37(3):90-95. (in Hungarian with English summary)

10. Frost, S. W. 1979. A preliminary study of North American insects associated with elderberry flowers. Florida Entomol. 62(4):341355.

11. Gleason, M. L., Taylor, S. E., Loughin, T. M., and Joehler, K. J. 1994. Development and validation of an empirical model to estimate the duration of dew periods. Plant Dis. 78:10111016.

12. Gubler, W. D., Marois, J. J., Bledsoe, A. M., and Bettiga, L. J. 1987. Control of Botrytis bunch rot of grape with canopy management. Plant Dis. 71:599-601.

13. Hewitt, H. G. 1998. Fungicides in Crop Protection. CAB International, Wallingford, UK.

14. Holb, I. J. 2005. Effect of pruning on apple scab in organic apple production. Plant Dis. 89:611-618.

15. Holb, I. J., and Heijne, B. 2001. Evaluating primary scab control in organic apple production. Gartenbauwissenschaft 66:254-261.

16. Holb, I. J., Heijne, B., and Jeger, M. J. 2003. Summer epidemics of apple scab: The relationship between measurements and their implications for the development of predictive models and threshold levels under different disease control regimes. J. Phytopathol. 151:335-343.

17. Holb, I. J., Heijne, B., Withagen, J. C. M., Gáll, J. M., and Jeger, M. J. 2005. Analysis of summer epidemic progress of apple scab at different apple production systems in the Netherlands and Hungary. Phytopathology
95:1001-1020.

18. Holb, I. J., Jong, P. F. de, and Heijne, B. 2003. Efficacy and phytotoxicity of lime sulphur in organic apple production. Ann. Appl. Biol. 142:225-233

19. Holb, I. J., and Scherm, H. 2007. Temporal dynamics of brown rot in different apple management systems and importance of dropped fruit for disease development. Phytopathology 97:1104-1111.

20. Holb, I. J., and Schnabel, G. 2005. Comparison of fungicide treatments combined with sanitation practices on brown rot blossom blight incidence, phytotoxicity, and yield for organic sour cherry production. Plant Dis. 89:1164-1170.

21. Iglisch, I. 1966. Untersuchungen über die Biologie und phytopathologische Bedeutung der Holunderblattlaus, Aphis sambuci L., einer der Aphis-fabae-Grouppe nahe verwandten Art (Homoptera: Aphididae). Mitt. Biol. Bund. Land. Forstw. 119:1-32.

22. Jensen, K., Christensen, L. P., Hansen, M., Jorgensen, U., and Kaack, K. 2000. Olfactory and quantitative analysis of volatiles in elderberry (Sambucus nigra L.) juice processed from seven cultivars. J. Sci. Food Agric. $81: 237-244$.

23. Kaack, K. 1988. Effect of nitrogen, planting distance and time for harvest on yield and fruit quality of elderberry (Sambucus nigra L.). Tidsskrift Planteavl 92:79-82. (in Danish)

24. Kaack, K. 1990. Growing elderberries. GronViden, Haveburg 46:6. (in Danish)

25. Kaack, K. 1997. 'Sampo' and 'Samdal', elderberry cultivars for juice concentrates. Fruit Var. J. 51:28.

26. Kaack, K., and Austed, T. 1998. Interaction of vitamin $\mathrm{C}$ and flavonoids in elderberry (Sambucus nigra L.) during juice processing. Plant Foods Hum. Nutr. 52:187-198.

27. Kaack, K., Christensen, L. P., Hughes, M., and Eder, R. 2005. The relationship between sensory quality and volatile compounds in raw juice processed from elderberries (Sambucus nigra L.). Eur. Food Res. Technol. 221:244254.

28. Kahn, B. A., Damicone, J. P., and Schatzer, R. J. 2005. Alternatives to benomyl for management of cercospora leaf spot on turnip greens. Hortscience 40:1324-1326.

29. Latham, A. J., and Hollingsworth, M. H. 1973. Incidence and control of sooty blotch and flyspeck of apples in Alabama. Auburn University Agricultural Experimental Station Circle 208.

30. Mezey, A., Mezey, G., Németh, I., Petz, A., and Simon, A. 2000. Plant protection problems in commercial growing of elderberry (Sambucus nigra L.) in Hungary. Plant Prot. 36:413423. (in Hungarian with English summary)

31. Ocamb-Basu, C. M., Sutton, T. B., and Nelson, L. A. 1988. The effects of pruning on incidence and severity of Zygophiala jamaicensis and Gloeodes pomigena infections of apple fruit. Phytopathology 78:1004-1008.

32. Paul, X., and Rossignol, Y. 1982. Sulphur as a fungicide. Sulphur Agric. 6:12-14

33. Peace, T. R. 1962. Pathology of Trees and Shrubs with Special Reference to Britain. Clarendon Press, Oxford, UK

34. Porpáczy, A. 1987. Elderberry. Pages 279-294 in: Currant, Blueberry, Elderberry, and Serviceberry. A. Porpáczy, ed. Mezőgazdasági Kiadó, Budapest, Hungary. (in Hungarian)

35. Porpáczy, A., and László, M. 1984. Evaluation of elderberry (Sambucus nigra L.) clones based on the quality of the fruit. Acta Alimen. 13:109-115.

36. Savage, S. D., and Sall, M. A. 1984. Botrytis bunch rot of grapes: Influence of trellis type and canopy microclimate. Phytopathology 74:65-70.

37. Sentelhas, P. C., Gillespie, T. J., Gleason, M. L., Monteiro, J.-E. B. A., and Helland, S. T. 2004. Operational exposure of leaf wetness sensors. Agric. For. Meteorol. 126:59-72.

38. Serkedjieva, J., Manolova, N., ZgórniakNowosielska, I., Zawilinska, B., and Grzybek, J. 1990. Antiviral activity of the infusion (SHS-174) from flowers of Sambucus nigra, aerial parts of Hypericum perforatum L., and roots of Saponaria officinalis L. against influenza and herpes simplex viruses. Phytother. Res. 4:97-100.

39. Starr, M. S., and Francis, F. J. 1968. Effect of ascorbic acid on the relative stability of four anthocyan pigments in cranberry juice. Food Technol. 22:1293.

40. Sutton, T. B., and Unrath, C. R. 1984. Evaluation of the tree-row-volume concept with density adjustments in relation to spray deposits in apple orchards. Plant Dis. 68:480-484.

41. Szeöke, K., and Nagy, K. 2006. Plant protection of elderberry (Sambucus nigra L.). Plant Prot. 42:265-280. (in Hungarian)

42. Takano, K. 1994. Leaf spot of Sambucus sieboldiana Bl. ex Grabn. caused by Cercospora depazeoides (Desmaz.) Saccardo. Ann. Phytopathol. Soc. Jpn. 60:777. (in Japanese)

43. Tamm, L., Häseli, J., Fuchs, J. G., Weibel, F. P., and Wyss, E. 2004. Organic fruit production in humid climates of Europe: Bottlenecks and new approaches in disease and pest control. Acta Hortic. 638:333-339.

44. Travis, J. W., Skroch, W. A., and Sutton, T. B. 1987. Effect of canopy density on pesticide deposition and distribution in Golden delicious apple trees. Plant Dis. 71:613-615.

45. Tweedy, B. G. 1981. Inorganic sulfur as a fungicide. Residue Rev. 78:43-68.

46. Wattenberg, L. W. 1990. Inhibition of carcinogenesis by minor nutrient constituents of the diet. Proc. Nutr. Soc. 49:173-183.

47. Way, R. D. 1981. Elderberry Culture in New York State. New York's Food and Life Sciences Bulletin No. 91. New York State Agricultural Experiment Station, Geneva, NY.

48. Zakay-Rones, Z., Thom, E., Wollan, T., and Wadstein, J. 2004. Randomized study of the efficacy and safety of oral elderberry extract in the treatment of influenza A and B virus infections. J. Int. Med. Res. 32:132-140. 